\title{
グルココルチコイド誘発性骨粗鬆症の病態と治療
}

\author{
金子開知，川合眞一
}

\section{Mechanisms and therapeutics of glucocorticoid-induced osteoporosis.}

\author{
Kaichi Kaneko, M. D. and Shinichi Kawai, M. D., Ph. D. \\ Division of Rheumatology, Department of Internal Medicine (Omori), Toho University School of Medicine, \\ 6-11-1 Omori-Nishi, Ota-ku, Tokyo 143-8541 Japan
}

(Received May 11, 2011)

\begin{abstract}
summary
Mechanisms of glucocorticoid-induced osteoporosis (GIOP) are categorized into local and systemic effects. In the local mechanisms, direct inhibitory effect of glucocorticoid on bone formation is thought to be one of the important mechanisms of GIOP. In contrast, secondary hyperparathyroidism induced by negative balance of calcium due to inhibition of absorption and increase of excretion is an important systemic mechanism of GIOP. Other mechanisms of GIOP are also shown in this review. From clinical points of view, serum markers for evaluation of GIOP have been discussed. Osteocalcin, procollagen type I N-terminal peptide, and bone-specific alkaline phosphatase as markers of bone formation are decreased in GIOP. Collagen I N-terminal telopeptide and tartrate resistent acid phosphatase isoform $5 \mathrm{~b}$ as markers of bone resorption are increased in GIOP.

Clinical guidelines have recommended that bisphosphonate is the first choice for the treatment of GIOP. Teriparatide is recombinant human parathyroid hormone $1-34$, which should be considered as a therapeutic option for those at high risk of bone fracture. Denosumab, an anti receptor activator of nuclear factor- $\beta$ ligand approved as a drug for postmenopausal osteoporosis was also effective for GIOP in clinical trials.
\end{abstract}

Key words glucocorticoid-induced osteoporosis; bisphosphonate; bone remodeling markers; receptor activator for nuclear factor $\kappa \mathrm{B}$ ligand; osteoprotegerin

抄録

グルココルチコイド（ステロイド）誘発性骨粗鬆症（GIOP）の発症機序は，ステロイドの骨組織の局所に対す る作用と, カルシウム代謝の変化による二次性副甲状腺機能六進症や下垂体ホルモン分泌抑制を介した性ホルモン 分泌の抑制などのステロイドが全身に作用を介した機序が考えられている．近年，骨組織への直接作用が特に骨形 成への影響が注目されている，骨代謝マーカーに抢いては，ステロイド投与早期より骨形成マーカーは低下する. 一方で, 骨吸収マーカーは増加傾向を示す. GIOP の治療に対して，各国でガイドラインが作成されているが，ビ スホスホネート製剤は GIOP に打ける骨折抑制効果が多くの臨床研究から明らかにされており治療の第一選択とな っている，また，ヒト組み換え副甲状腺ホルモン剤であるテリパラチドは，GIOPに拈ける骨折のリスクが高い患 者に拈いて使用を考慮すべき薬剤である。さらに，抗 receptor activator for nuclear factor $\kappa \mathrm{B}$ ligand 抗体製剤であ るデノスマブは閉経後骨粗鬆症においての有用性が報告されており GIOPでの効果が今後期待される.

\section{はじめに}

グルココルチコイド（以下ステロイド）は，近代 医学に最も貢献した代表的薬物の 1 つである. その 臨床応用は，1948 年 9 月 21 日に Hench が合成コ ルチゾンをはじめて関節リウマチ患者に用いたこと に始まる11).その後, ステロイドはきわめて多くの

東邦大学医学部内科学講座 (大森)膠原病科
疾患の治療薬として使われるようになったが，膠原 病疾患の治療薬として欠かすことのできない薬剂で ある.しかし，この薬物には顕著な有効性とともに 重篤な副作用があり，これらをどうしても切り離せ ないことが最大の問題点となっている. 図 1 は 10 年以上に及ぶステロイド療法により多発性の脊椎椎 体圧迫骨折をきたした全身性エリテマトーデスの 40 歳女性の胸腰椎 MRI 画像である. ステロイド誘 発性骨粗鬆症 (glucocorticoid-induced osteoporo- 
sis, GIOP）とそれに続発する骨折は，頻度および 重症度とともに高く, 病的骨折を合併すれば QOL （quality of life）を著しく障害する危険性もある， 極めて重症の合併症であり, 膠原病治療の大きな課 題となっている2). 本稿では, GIOP の病態と治療 について筆者らの成績を含めて概説する.

\section{I. ステロイド誘発性骨粗鬆症の発症機序}

GIOPの発症機序として，ステロイドの骨組織の 局所に対する作用と，カルシウム代謝の変化による 二次性副甲状腺機能充進症や下垂体ホルモン分泌抑
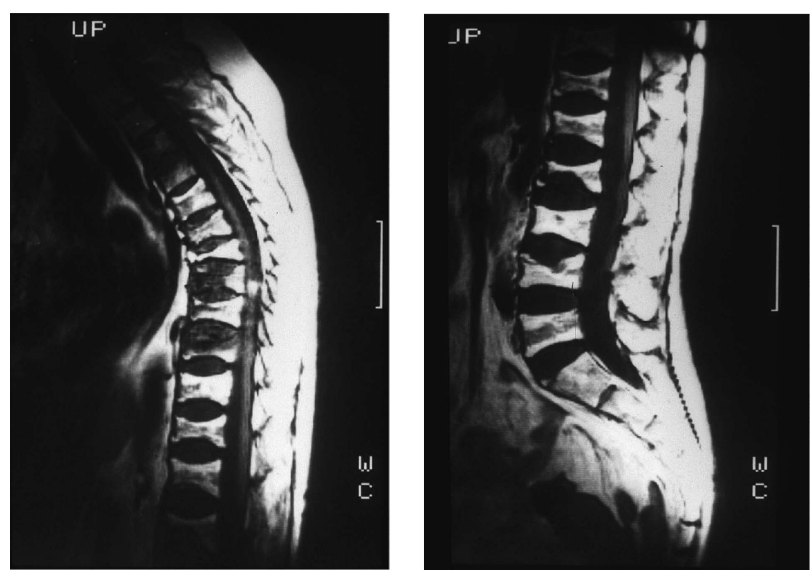

図 1 ステロイド療法による多発性脊椎椎体骨折 (40 歳女性, 全身性エリテマトーデス）
制を介した性ホルモン分泌の抑制などのステロイド が全身に作用を介した機序が考えられている．筆者 らがまとめた発症機序を図 2 に示した。

\section{1. ステロイドの骨局所に対する作用 \\ 1）骨芽細胞への作用}

GIOP の発症要因として骨組織の直接作用が注目 されており，特に骨形成への影響が重要と考えられ ている ${ }^{3-5)}$ ．ステロイドは幹細胞から骨芽細胞への 分化に重要な転写因子 Runx2/Cbfa1 を抑制するこ とにより，骨芽細胞への分化を阻害する6) . peroxisome proliferator-activated receptor $\gamma(\operatorname{PPAR} \gamma)$ は，骨髄間質細胞から脂肪細胞への分化を促す核内 受容体型転写因子であることが知られている，ステ ロイドは, PPAR $\gamma$ の発現を増加させ脂肪細胞分化 が増大し，骨芽細胞へと分化する細胞が減少するこ とも原因のひとつと考えられている7). また，ステ ロイドは，未分化間葉系細胞から骨芽細胞への分 化・増殖機能を抑制し，骨芽細胞のアポトーシスを 誘導する ${ }^{8)}$. その結果, 骨芽細胞数と活性の低下が 起こり骨形成低下を引き扢こす，さらに，ステロイ ドは I 型コラーゲン, オステオカルシンや, 成長因 子である insulin-like growth factor (IGF), tumor growth factor $\beta(\mathrm{TGF}-\beta)$ の産生を低下し, 骨形成 の低下を引き抢こす 8 11).

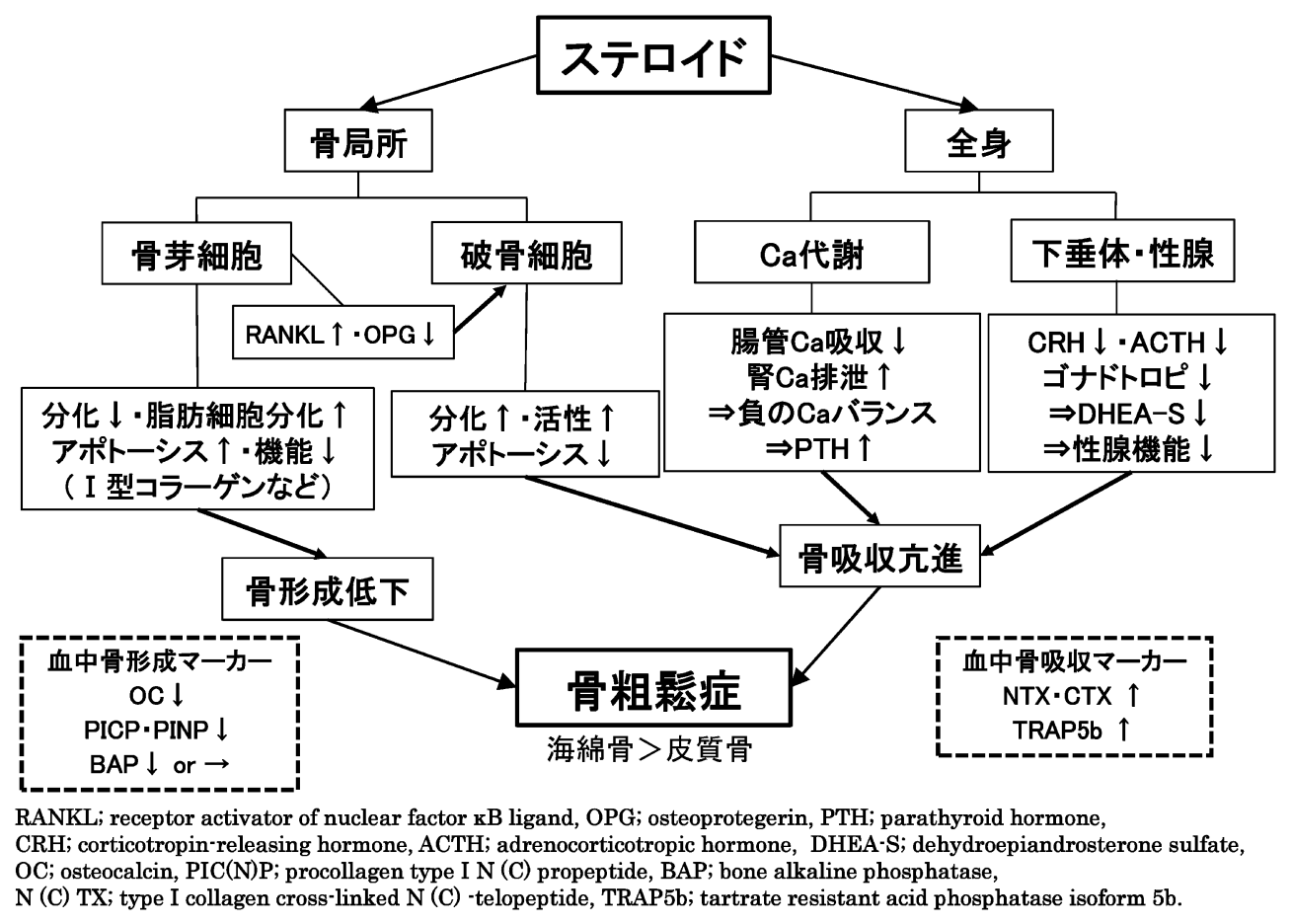

図 2 ステロイド性骨粗鬆症の発症機序 
骨局所では, GIOP の発症機序として骨芽細胞が 発現する receptor activator for nuclear factor $\kappa \mathrm{B}$ ligand (RANKL) と osteoprotegerin (OPG) の破 骨細胞への影響が注目されている ${ }^{12)}$. RANKL は, 破骨細胞の前駆細胞表面に発現される受容体 RANK と結合することにより成熟破骨細胞となり 骨吸収が活発となる。OPGは，RANKより高い親 和性で RANKL に結合し破骨細胞の活性化を抑制 する，デコイ受容体である，ステロイドは，この破 骨細胞分化因子である RANKL の発現を増強する とともに, OPG の産生を抑制し破骨細胞形成を促 進する13).

\section{2）破骨細胞への作用}

ステロイドは破骨細胞の成熟，活性化を調節す る.これは，前述した RANKL と OPG の関与が大 きいが，加えてステロイドは破骨細胞のアポトーシ スを抑制することが知られている14)。すなわち，ス テロイドにより破骨細胞前駆細胞から破骨細胞への 分化が促進され，また破骨細胞のライフスパンが延 長し，骨吸収が充進すると考えられている.

\section{2. ステロイドの全身に対する作用}

1） カルシウム代謝

ステロイドは十二指腸および上部空腸でのカルシ ウム吸収を直接的に低下させる ${ }^{15)}$ 。また，ステロイ ドは一部活性型ビタミン $\mathrm{D}_{3}$ 産生を低下させカルシ ウム吸収を抑制する。腸管からのカルシウム吸収が 低下し，カルシウム欠乏状態により二次性副甲状腺 機能充進症を発症させ骨吸収が増大する。一方，又 テロイドは尿中へのカルシウム排泄を増加させる. この機序として，ステロイドによる腎糸球体濾過量 増加に伴う二次的な影響と腎尿細管への直接的な作 用によるカルシウム再吸収の抑制し，尿中へのカル シウム排泄を増加させることが機序と考えられてい る ${ }^{16)}$ 。これらの作用により, 体内のカルシウムは負 のバランスを取る。

\section{2）副甲状腺ホルモン（parathyroid hormone,} PTH)

ステロイドによりカルシウム吸収の低下と腎にお けるカルシウムの負のバランスが生じると, 二次性 副甲状腺機能立進症を合併する17,18). 高濃度の PTH に持続的に曝露された場合には，破骨細胞を 介した骨吸収が増加する19).

\section{3）下垂体ホルモン}

過剩量のステロイドは, ネガティブフィードバッ
クにより視床下部の副腎皮質刺激ホルモン放出ホル モン (corticotropin-releasing hormone, CRH) 及び ゴナドトロピンの分泌を抑制する。その結果下垂 体の黄体化ホルモン (Luteinizing hormone, LH), 卵胞刺激ホルモン (Follicle stimulating hormone, FSH)，副腎皮質刺激ホルモン（adrenocorticotropic hormone, ACTH） 分泌を抑制してエストロゲ ン，テストステロン， DHEA (dehydroepiandrosterone), DHEA-S (dehydroepiandrosterone sulfate) の分泌を低下させる.エストロゲンなどの低下は骨 吸收を促進し骨粗鬆症を進展させる。なお，ステロ イドは直接下垂体のホルモン分泌を低下させる作用 もある。

\section{GIOP の特徵}

正常な骨では，リモデリングに抢ける骨吸収と骨 形成のバランスが保たれているため骨量は減少しな い. 原発性骨粗鬆症の病因の主体は，閉経後にエス トロゲンが欠乏することである．エストロゲンが久 そすることにより，骨吸収が異常に克進するもの の，骨形成が追いつかないため，結果的には骨吸収 が優位となり骨量は減少する。このように原発性骨 粗鬆症は，骨の代謝回転が高くなっているため高代 謝回転の骨粗鬆症となる。一方で，GIOP は原発性 骨粗鬆症と異なり，前述の機序により，低代謝回転 の骨粗鬆症をもたらす。GIOP における骨量減少 は，原発性骨粗鬆症とは異なり皮質骨よりもリモデ リングの盛んな海綿骨に抢いて著しく，股関節より も先に春椎の骨量が減少し, 脊椎および胁骨骨折を 合併しやすい特徵をもつ。これは内因性ステロイド の過剰状態である Cushing 症候群でも同様のこと が報告されている20).

GIOP の臨床所見の特徵は，骨減少の起きる時期 が二相性であり，治療開始直後の減少が著明である 点である，また，同じ骨密度であっても，原発性骨 粗鬆症と比較すると GIOP のほうが，はるかに骨 折率が高い点である ${ }^{21)}$.

\section{III. 骨代謝マーカー}

骨組織の動態を正確に解析するには骨生検による 骨形態計測法が最も信頼のおける解析法であるが, 骨生検は観血的であり，繰り返し採取することは一 般臨床では困難である。そこで現在では，骨組織の 動態を非侵襲的に測定するッールとして骨代謝マ一 カーが代用され，その重要度が高まっている，ステ 
ロイド投与後の骨代謝マーカーの变動の特徵に関し て自検例で述べる.

\section{1. 骨形成マーカー}

筆者らは，それまで未治療でプレドニゾロン 30 $\mathrm{mg} /$ 日以上の治療を開始し, 同時にビスホスホネー 卜製剂を併用した活動期膠原病患者 40 例（55 \pm 16 歳 $[$ 平均 $\pm \mathrm{SD}$ ，女性 29 例・閉経後 16 例）を対象 に，血清骨代謝マーカーを経時的に測定した ${ }^{22)}$ 。骨 形成マーカーは, 骨芽細胞表面にある骨型アルカリ ホスファターゼ (BAP) と, I 型コラーゲン生産過 程で産生される I 型プロコラーゲン $\mathrm{N}$ 末端プロペ プチド（PINP）があり，このほかに骨芽細胞で産 生されるオステオカルシン（OC）などを用いた。 なお， OC は骨芽細胞が産生するビタミン $\mathrm{K}$ 依存性 タンパク質であり，ビタミン $\mathrm{K}$ は OC のグルタミ ン酸残基のカルボキシル化（Gla 化）に関与し，骨 質を維持すると考えられている．そのため，ビタミ ン $\mathrm{K}$ 不足になると低カルボキシル化オステオカル シン（ucOC）が増加し，血中 ucOC 濃度が上昇す る. 血中 $\mathrm{ucOC}$ 濃度は, 骨に抢けるビタミン $\mathrm{K}$ 不 足のマーカーであると同時に, 高 ucOC 血症は骨折 の予測因子としても有用である可能性が示唆されて いる23,24).

図 3 に示すようにステロイド療法後の血清 OC, $\mathrm{ucOC}$ 濃度の变動はステロイド治療 1 週後から有意
に減少し, 治療 4 週後も継続していた。 ucOC/OC 比はステロイド治療 1 週後から有意に低下し, 治療 4 週後も持続した。 ucOC/OC 比の結果より $\mathrm{ucOC}$ はステロイド療法により total OC の中で低下率が 高い事がわかり，それは骨形成維持するための代償 的な作用が生体内で生じているのではないかと考え られた。

ステロイド投与直後に血清 P I NP は急激に低下 し4週まで持続した（図 4).この結果は,すでに 報告されている結果と一致している9,18,25 35). 一方 で, 血清 BAP の変動は, ステロイド投与後も変化 を認めなかった（図 4). 今までのステロイド投与 後の血清BAP の変動では, 低下するとの報 告18,28,31) もあれば変化しないとの報告9,29,30) があ る.この血清 OC, P I NP と BAP の変動の違いに ついて OC, P I NP 遺伝子は直接ステロイドの制御 を受けるが，BAP 遺伝子上流にはステロイド受容 体領域がないことやマーカーの半減期の違いのため と考えられている36,37).

\section{2. 骨吸収マーカー}

骨吸収マーカーには, I 型コラーゲンが破骨細胞 により分解されて放出される代謝産物 I 型コラーゲ ン架橋 $\mathrm{N}$-テロペプチド（NTx），デオキシピリジ， リン (DPD), 破骨細胞が分泌する酒石酸抵抗性酸 性ホスファターゼ（TRAP5b）などが用いられる.
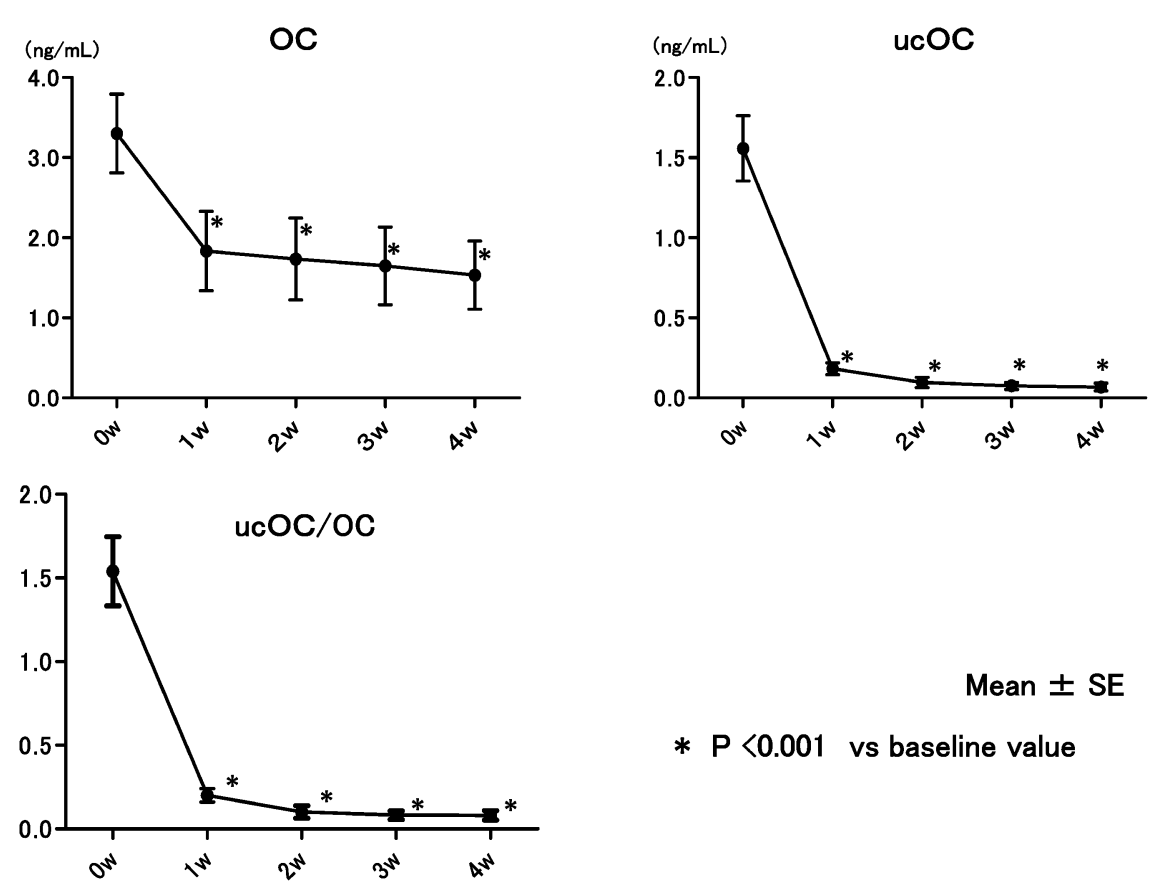

Mean \pm SE

* $\mathrm{P}<0.001$ vs baseline value

図 3 血清 $\mathrm{OC}, \mathrm{ucOC}, \mathrm{ucOC} / \mathrm{OC}$ ratio $の$ 変動 22$)$ 

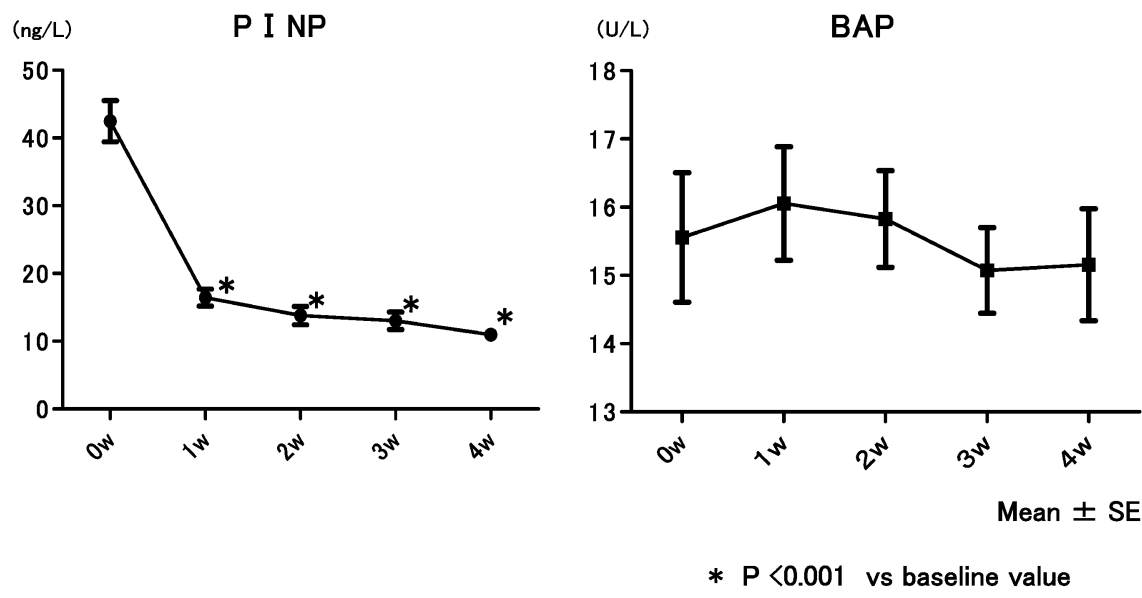

図 4 血清 P I NP, BAP の変動 22

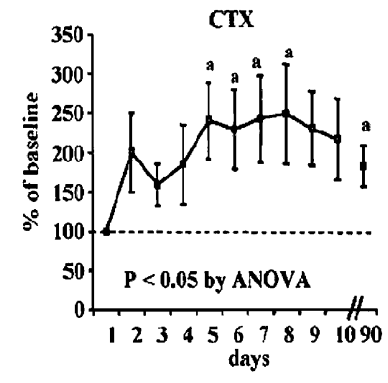

多発性硬化症にメチルプレドニゾロン $15 \mathrm{mg} / \mathrm{kg} /$ 日を 10日間投与した際の血清CTXの変動 ${ }^{41)}$
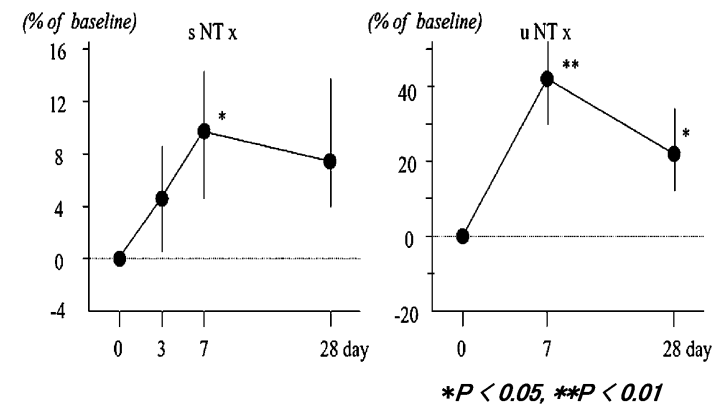

自己免疫性疾患にプレドニゾロン $40 \mathrm{mg} /$ 日以上を投与 した際の血清·尿中NTXの変動 ${ }^{42)}$

図 5 骨吸收マーカーの変動

ステロイド療法後の骨吸収マーカーの変動は上昇を 示す25,28,29,31,32,39,40). 特に, 図 5 に示すように骨粗 鬆症薬を併用せずにステロイド大量療法を行った前 向き研究での骨吸収マーカーの変動は, ステロイド 療法 1 カ月以内の短期間で上昇を示している ${ }^{41,42)}$.

\section{3. 血清 RANKL, OPG}

血液や滑液に存在する血清 RANKL と OPG は, 様々な骨代謝疾患に扮いて増減する（表 1 ${ }^{43}$. Hofbauer ら ${ }^{13)}$ は，in vitroに抢いて骨芽細胞様細胞 にデキサメサゾンを添加すると OPG 産生が減少 し, 可溶性 RANKL 産生が増加することを示して いる．Sasaki ら ${ }^{32}$ は，慢性系球体腎炎患者におい て，ステロイドにより血清 OPG は低下し，その後 6 力月まで低下は持続し, 骨密度も有意に低下した ことを報告し，前述の in vitroの成績を支持してい る。これは，GIOP において，OPG 産生抑制によ る破骨細胞形成促進が骨量低下の一因となることを 示しているが，GIOP における血清 RANKL の意 義については明らかにされていない。
表 1 血清 OPG とRANKL に影響を及ぼす要因43)

\begin{tabular}{lcc}
\hline \hline \multicolumn{1}{c}{ パラメーター } & 血清 OPG & 血清 RANKL \\
\hline 年齢 & $\uparrow$ & $?$ \\
関節炎 & $\uparrow$ & $\downarrow$ \\
ビスホスホネート製剤治療 & $\downarrow \leftrightarrow$ & $\leftrightarrow$ \\
エストロゲン治療 & $\uparrow \downarrow$ & $\downarrow \leftrightarrow$ \\
骨折治癒 & $\downarrow$ & $?$ \\
ステロイド治療 & $\downarrow$ & $?$ \\
多発性骨髄腫 & $\downarrow$ & $\uparrow$ \\
Paget 病 & $\uparrow$ & $\leftrightarrow$ \\
副甲状腺ホルモン & $\downarrow$ & $\uparrow$ \\
副甲状腺切除術 & $\leftrightarrow$ & $?$ \\
フィトエストロゲン & $\leftrightarrow$ & $\downarrow$ \\
閉経後骨粗鬆症 & $\uparrow \downarrow$ & $\uparrow \downarrow$ \\
妊娠 & $\uparrow$ & $?$ \\
原発性胆汁性肝硬変 & $\uparrow$ & $\downarrow$ \\
前立腺癌 & $\uparrow$ & $\uparrow$ \\
腎不全 & $\uparrow$ & $?$ \\
骨粗鬆症性骨折のリスク & $\uparrow \downarrow$ & $\uparrow \downarrow$ \\
血管疾患 & $\uparrow$ & $?$ \\
\hline
\end{tabular}




\section{GIOP の治療}

\section{1. 治療薬の種類}

現在，日本骨粗鬆症学会による「骨粗鬆症の予防 と治療のガイドライン 2006 年版」においてビスホ スホネート製剤は最も高いグレード評価を受けてい る44)。これは，GIOP における骨折抑制にも有効で あることが多くの臨床研究から明らかにされてい る. 我国で骨粗鬆症治療薬に用いられているアレン ドロネート，リセドロネート，エチドロネートのい ずれのビスホスホネート製剤についても，GIOP に 抢ける骨折抑制効果が明らかにされている45 48). カルシウム剤及び活性型ビタミン $\mathrm{D}^{3}$ 製剂は，ステ ロイドによるカルシウムの負のバランスを是正する 可能性から用いられ GIOPに抢ける椎体骨折抑制 におけるその有効性が認められている49)。ただし， ステロイドは尿中カルシウム排泄を増加させ腎結石 を誘発しやすいことはすでに知られており，プレド ニゾロンの添付文書においても，活性型ビタミン $\mathrm{D}_{3}$ 製剂併用で，高カルシウム尿症，尿路結石があ らわれることがあるので，併用する場合には，定期 的に検査を行う必要がある. 我国では骨粗鬆症に対 して処方されているビタミン $\mathrm{K}_{2}$ は, 欧米では骨粗 鬆症治療薬として用いられていないために GIOP における臨床成績は乏しい，GIOP の新しい薬剤と
しては最近発売されたテリパラチドがある.テリパ ラチドはヒト組み換え副甲状腺ホルモン剂 PTH （1-34）であり，毎日皮下注射する．Saag ら ${ }^{50)} は ，$ GIOP の患者に対してテリパラチドとアレンドロ ネートの無作為二重盲検試験を行い, 腰椎および大 腿骨でテリパラチドはアレンドロネートよりも顕著 に骨密度を増加させることを示しており GIOPの 新しい薬剤として期待される.

2. GIOP の管理と治療のガイドライン

1）日本骨代謝学会によるステロイド性骨粗鬆症 の管理と治療のガイドライン

GIOP における骨折抑制を指標とした薬剂の治療 効果が明らかとなりつつある現状を踏をえて, 積極 的に骨を守る治療を行うべき対象を明確にすること と具体的な治療方針を明示することが求められるよ うになってきた。このような背景から，我国では， 2004 年に日本骨代謝学会から「ステロイド性骨粗 鬆症の管理と治療のガイドライン」が提唱された (図 6) ${ }^{51)}$ 。これは簡便にスクリーニングできるよう にフローチャート形式となって打り, 日常診療の現 場において無理なく活用できるものになっている. このフローチャートでは, 現在ステロイド治療を受 けているいないにかかわらず，今後 3 カ月以上ステ ロイド治療を行う予定の患者であり, 既存骨折の有

経ロステロイドを3カ月以上使用中または使用予定 1

\section{すでに脆弱性骨折注2)がある、または治療中に骨折}

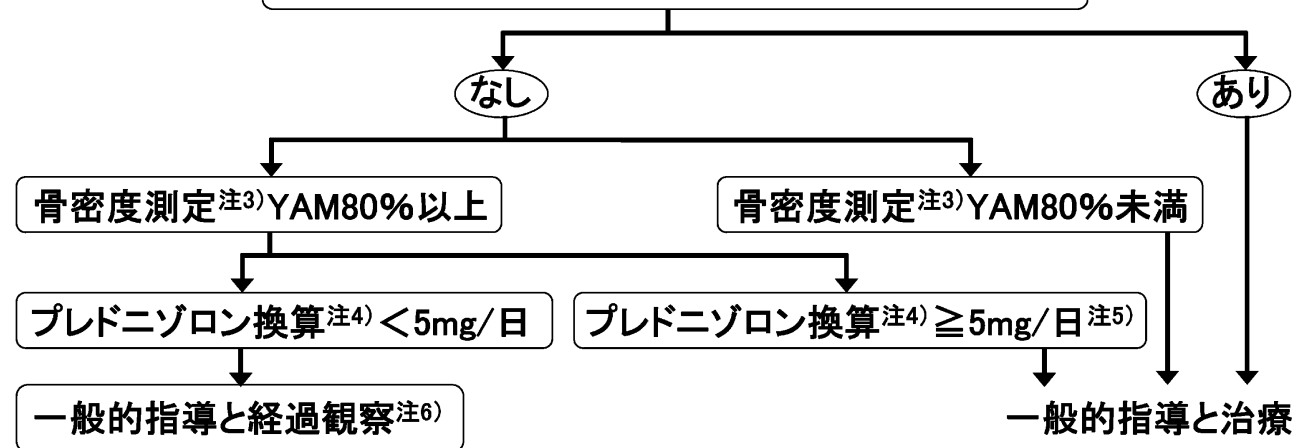

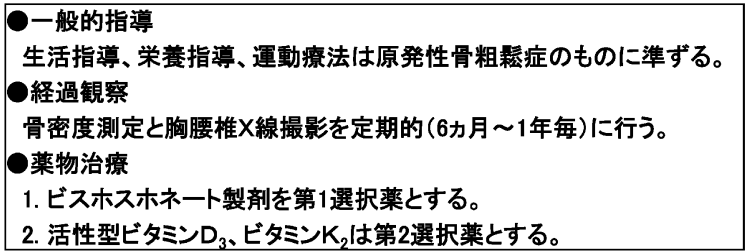

タミンK2は第2選択薬とする。
注1)本ガイドラインは18歳以上を対象とする。

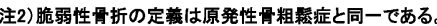

注3)骨密度測定は原発性骨粗稳症 (2000年度改訂版)に準ずる。

注3)骨密度測定は原

注5)1日10mg以上の使用例では骨密度が高くても骨折の危険性がある。

(骨折閖值\%YAM90)。

注6)高龄者では骨折の危険性が高くなる。

図 6 ステロイド性骨粗鬆症の管理と治療のガイドライン (2004 年度版 $)^{51)}$ 
無と骨密度，および使用予定ステロイド量により振 り分けていく，既存骨折が有り，骨密度が $80 \%$ 未 満，今後のステロイド使用量がプレドニゾロン換算 で $5 \mathrm{mg}$ /日以上のいずれかを満たす場合に一般指導 に加えて積極的な治療が勧められる。いずれに該当 しない場合でも，一般指導と慎重な経過観察となる が，この群に入る患者でも，原発性骨粗鬆症患者よ りは骨折リスクが高いとされていることに注意する 必要がある，治療が必要とされる場合には，第 1 選 択薬としてビスホスホネートが推奨されている.ビ スホスホネートが内服出来ない場合には, 活性型ビ タミン $\mathrm{D}_{3}$ もしくはビタミン $\mathrm{K}_{2}$ が第 2 選択薬とし てあげられている。

2） 2010 年アメリカリウマチ学会による GIOP の予防と治療の推奨

2010 年アメリカリウマチ学会（ACR，American College of Rheumatology）は，GIOP の予防と治療 の最新版の推奨を提唱した ${ }^{52)}$. 今回の推奖の最大の 特徵としては, FRAX ${ }^{\circledR}$ (Fracture Risk Assessment Tool）と呼ばれる骨折リスク評価ツールを導入し たことである.

FRAX ${ }^{\circledR}$ は界保健機構（WHO, world health organization）が新たに骨粗鬆症治療介入の基準々 して提案した 10 年間の骨折リスクを評価するッー ルである ${ }^{53)}$. (1)年齢(2)性別(3)体重(4)身長(5)骨折歴(6)
両親の大腿骨近位部骨折歴(7)現在の喫煙(8)糖質コル チコイド使用(9)関節リウマチの有無(10)続発性骨粗鬆 症の有無(11)アルコール摂取 (12)大腿骨頸部 BMD (bone mineral density) の計 12 個のチェック項目 から構成される，FRAX ${ }^{\circledR}$ をいる場合は主要骨粗 鬆症関連骨折リスクが $20 \%$ 以上を高リスク， $10 \%$ から 20\%を中等度リスク，10\%未満を低リスクと している。この FRAX ${ }^{\circledR}$ が導入されるようになった 背景としては，ステロイド治療中の患者に抢いて， 骨密度の久頼っていたのでは骨折予防が出来ないと いうことが認識されるようになったためである ${ }^{54)}$.

図 7 に閉経後女性または 50 歳以上の男性にステ ロイド治療を開始する（している）患者への推奨を 示す．低抢よび中等度リスク患者では， 3 カ月以上 のステロイド使用が予測される患者，または既に少 なくとも 3 カ月間のステロイド治療を受けている患 者に対してビスホスホネート製剤の投与を開始する ものとする，また，高リスク患者において，ステロ イドの量が $5 \mathrm{mg} /$ 日を超えて 1 カ月以下，またはい かなる用量でも 1 力月超える場合ビスホスホネート 製剂またはテリパラチドが推奨されている.図 8 に 閉経前女性または 50 歳未満の男性にステロイド治 療を開始する（している）患者の推奖を示す．現在 のところ, 閉経前女性または 50 歳未満の男性での GIOP のエビデンスは限られたものしかなく，

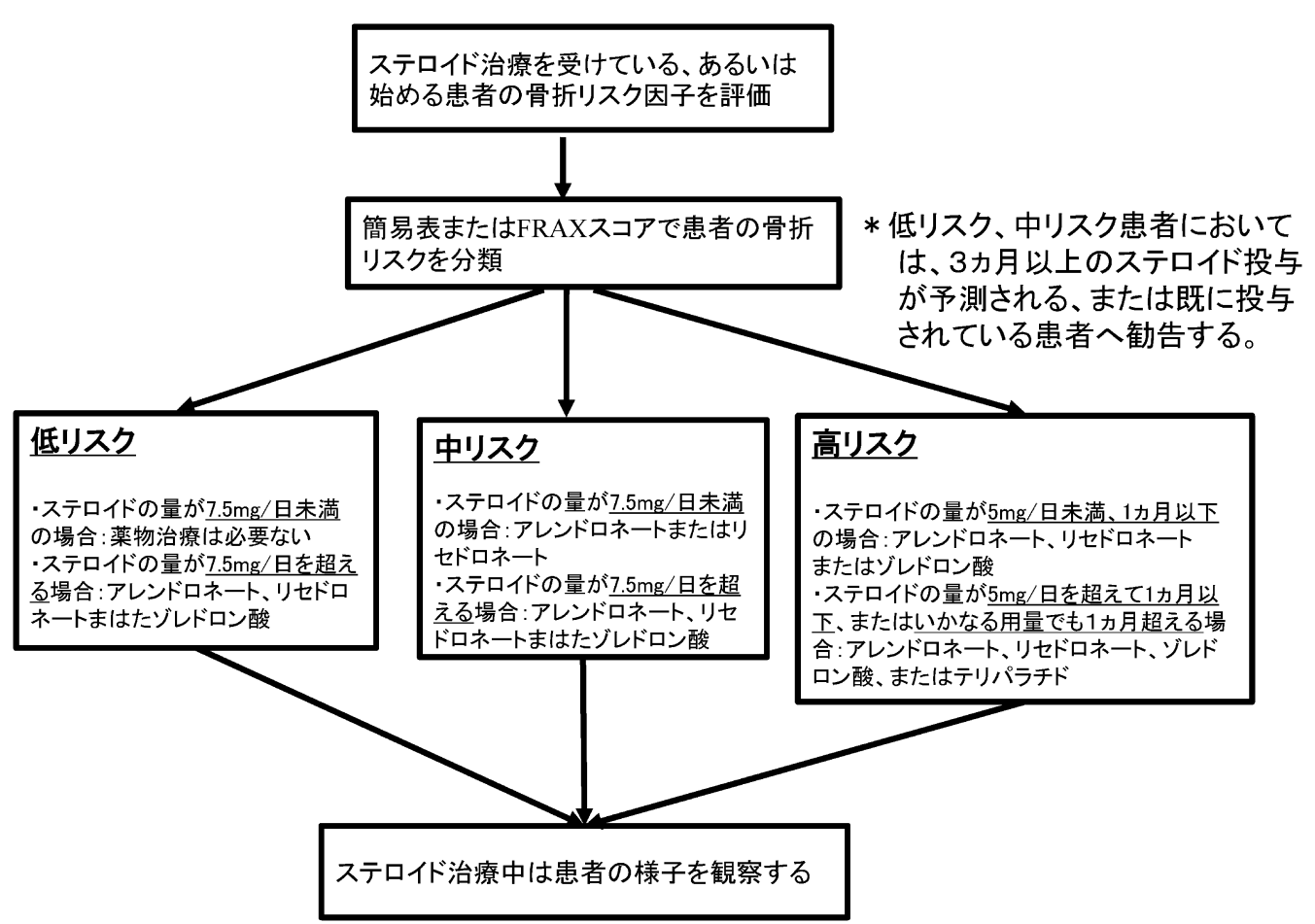

図 7 閉経後女性または 50 歳以上の男性にステロイド治療を開始する(している) ときの推奨52 


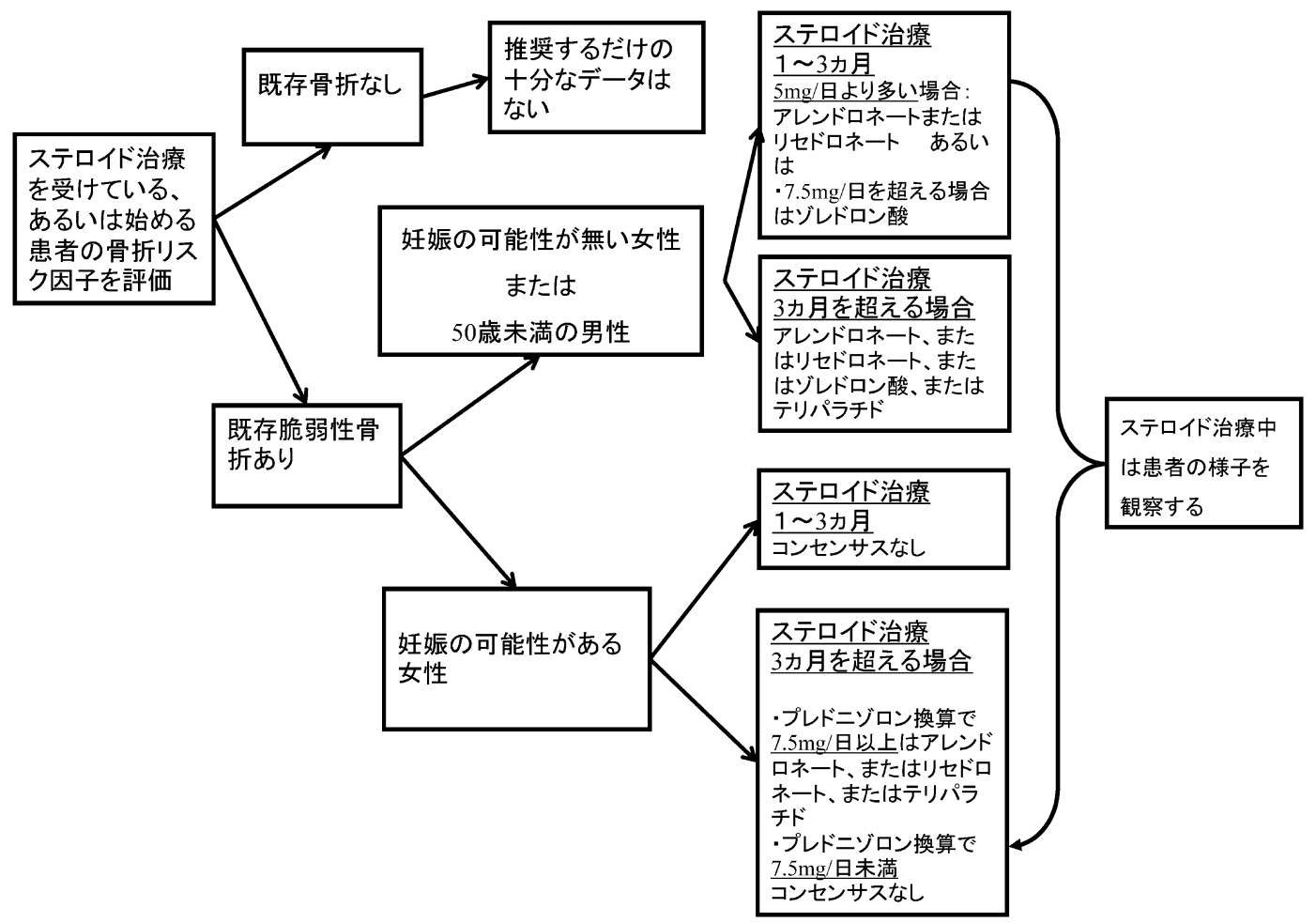

図 8 閉経前女性または 50 歳未満の男性にステロイド治療を開始する(している)ときの推奨52)

$\mathrm{FRAX}^{\circledR}$ もこれらの対象群には適応されない。妊娠 中あるいは妊娠前の骨粗鬆症治療薬の使用に関して 詳細は明らかになっていない，妊娠の可能性のある 女性においては半減期の短い薬剤が推奨されてい る. 妊娠可能性のない女性においてはステロイドの 治療期間が 3 カ月以上とういう点以外は, 閉経後女 性抢よび 50 歳以上の男性と同様の推奨となってい る.

今回の ACR による推奨は, FRAX $^{\circledR}$ に大きく依 存しており問題点について考慮する必要がある。ま ずステロイド使用に関するリスクに関して用量反応 性が考慮されていない点があげられる。 またステロ イド治療を受けている患者では一般的に大腿骨頸部 よりも先に脊椎の骨量が失われる。これらの点によ り骨折リスクが過小評価される可能性があり注意し なければならない。

\section{おわりに}

GIOP の病態と治療, 骨代謝マーカーの変動につ いてまとめてみた。本邦のガイドライン， ACRの 推奨に拈いて GIOP の治療はビスホスホネート製 剂が中心となっている.しかしながら，ステロイド 投与早期における病態においては骨芽細胞の抑制が 重要であり, 新規にステロイド療法を行う際の骨粗
鬆症の予防には, 骨吸収抑制薬であるビスホスホ ネート製剂の併用に加え, 骨形成抑制に対する対策 も重要であると考えられる。 また GIOP の原因の 一つとして，RANKL-OPG 系を介した破骨細胞分 化誘導作用が関与していると考えられ, 今後抗 RANKL 抗体製剤（denosumab）による GIOP での 効果が期待される.

\section{文献}

1) Hench PS, Kendall EC, Slocumb $\mathrm{CH}$,et al. : The effect of a hormone of the adrenal cortex (17-hydroxy-11-dehydrocorticosterone ; compound E) and of pituitary adrenocorticotropic hormone on rheumatoid arthritis. Mayo Clin Proc. 24 : 181-197, 1949.

2) Zonana-Nacach A, Barr SG, Magder LS, Petri M. Damage in systemic lupus erythematosus and its association with corticosteroids. Arthritis Rheum. 43 : 1801-1808, 2000.

3) Chappard D, Legrand E, Basle MF, Fromont P, Racineux JL, Rebel A, Audran M. : Altered trabecular architecture induced by corticosteroids : a bone histomorphometric study. J Bone Miner Res. 11 : 676-685, 1996.

4) Dalle Carbonare L, Arlot ME, Chavassieux PM, Roux JP, Portero NR, Meunier PJ. : 
Comparison of trabecular bone microarchitecture and remodeling in glucocorticoid-induced and postmenopausal osteoporosis. J Bone Miner Res. 16 : 97-103, 2001.

5) Tamura Y, Okinaga H, Takami H. : Glucocorticoid-induced osteoporosis. Biomed Pharmacother. 58 : 500-504, 2004.

6) Chang DJ, Ji C, Kim KK, Casinghino S, McCarthy TL, Centrella M.: Reduction in transforming growth factor beta receptor I expression and transcription factor $\mathrm{CBFa} 1$ on bone cells by glucocorticoid. J Biol Chem. 273 : 4892-4896, 1998.

7) Shi XM, Blair HC, Yang $X$, McDonald JM, Cao X. : Tandem repeat of $\mathrm{C} / \mathrm{EBP}$ binding sites mediates PPARgamma2 gene transcription in glucocorticoid-induced adipocyte differentiation. J Cell Biochem. 76 : 518-527, 2000.

8) Weinstein RS, Jilka RL, Parfitt AM, Manolagas SC. : Inhibition of osteoblastogenesis and promotion of apoptosis of osteoblasts and osteocytes by glucocorticoids. Potential mechanisms of their deleterious effects on bone. J Clin Invest. 102 : 274-282, 1998.

9) Lems WF, Gerrits MI, Jacobs JW, van Vugt RM, van Rijn HJ, Bijlsma JW. : Changes in (markers of) bone metabolism during high dose corticosteroid pulse treatment in patients with rheumatoid arthritis. Ann Rheum Dis. 55 : 288-293, 1996.

10) Delany AM, Durant D, Canalis E. : Glucocorticoid suppression of IGF I transcription in osteoblasts. Mol Endocrinol. 15 : 1781-1789, 2001.

11) Centrella M, McCarthy TL, Canalis E. : Glucocorticoid regulation of transforming growth factor beta 1 activity and binding in osteoblast-enriched cultures from fetal rat bone. Mol Cell Biol. 11 : 4490-4496, 1991.

12) Suda T, Takahashi N, Udagawa N, Jimi E, Gillespie MT, Martin TJ. : Modulation of osteoclast differentiation and function by the new members of the tumor necrosis factor receptor and ligand families. Endocr Rev. 20 : 345-357, 1999.

13) Hofbauer LC, Gori F, Riggs BL, Lacey DL, Dunstan CR, Spelsberg TC, Khosla S. : Stimulation of osteoprotegerin ligand and inhibition of osteoprotegerin production by glucocorticoids in human osteoblastic lineage cells : potential paracrine mechanisms of glucocorti- coid-induced osteoporosis. Endocrinology. 140 : 4382-4389, 1999.

14) Weinstein RS, Chen JR, Powers CC, Stewart SA, Landes RD, Bellido T, Jilka RL, Parfitt AM, Manolagas SC. : Promotion of osteoclast survival and antagonism of bisphosphonate-induced osteoclast apoptosis by glucocorticoids. $J$ Clin Invest. 109 : 1041-1048, 2002.

15) Hahn TJ, Halstead LR, Baran DT. : Effects of short term glucocorticoid administration on intestinal calcium absorption and circulating vitamin D metabolite concentrations in man. J Clin Endocrinol Metab. 52 : 111-115, 1981.

16) Suzuki Y, Ichikawa Y, Saito E, Homma M. : Importance of increased urinary calcium excretion in the development of secondary hyperparathyroidism of patients under glucocorticoid therapy. Metabolism. 32 : 151-156, 1983.

17) Paz-Pacheco E, Fuleihan GE, LeBoff MS. : Intact parathyroid hormone levels are not elevated in glucocorticoid-treated subjects. J Bone Miner Res. 10 : 1713-1718, 1995.

18) Pearce G, Tabensky DA, Delmas PD, Baker HW, Seeman E. : Corticosteroid-induced bone loss in men. J Clin Endocrinol Metab. 83 : 801806, 1998.

19) John T. Potts. : Disease of the Parathyroid Gland and Other Hyper- and Hypocalcemic Disorders. Fauci AS eds. Harrison's Principles of Internal Medicine, 17th Ed., McGrawHill, New York, p2377-2396, 2008.

20) Chiodini I, Carnevale V, Torlontano M, Fusilli S, Guglielmi G, Pileri M, Modoni S, Di Giorgio A, Liuzzi A, Minisola S, Cammisa M, Trischitta V, Scillitani A. : Alterations of bone turnover and bone mass at different skeletal sites due to pure glucocorticoid excess : study in eumenorrheic patients with Cushing's syndrome. J Clin Endocrinol Metab. 83 : 1863-1867, 1998.

21) Manolagas SC, Weinstein RS. : New developments in the pathogenesis and treatment of steroid-induced osteoporosis. J Bone Miner Res. 14 : 1061-1066, 1999.

22）金子開知, 田中菜穂子, 楠 夏子, 山本竜 大, 鏑木 誠, 村岡 成, 楠 芳恵, 阿部治 男, 遠藤平仁, 川合眞一: Bisphosphonate 製 剂併用のステロイド療法による骨代謝マー カー変動に関する前向き研究. 日本リウマチ 学会総会・学術集会・国際リウマチシンポジ ウムプログラム・抄録集. 54 回. 2010. p. 240 . 
23) Plantalech L, Guillaumont M, Vergnaud P, Leclercq M, Delmas PD. : Impairment of gamma carboxylation of circulating osteocalcin (bone gla protein) in elderly women. $J$ Bone Miner Res. 6 : 1211-1216, 1991.

24) Vergnaud P, Garnero P, Meunier PJ, Bréart G, Kamihagi K, Delmas PD : Undercarboxylated osteocalcin measured with a specific immunoassay predicts hip fracture in elderly women : the EPIDOS Study. J Clin Endocrinol Metab. 82 : 719-724, 1997.

25) Cosman F, Nieves J, Herbert J, Shen V, Lindsay R.: High-dose glucocorticoids in multiple sclerosis patients exert direct effects on the kidney and skeleton. $J$ Bone Miner Res. 9 : 1097-1105, 1994.

26) Fujita $T$, Satomura A, Hidaka M, Ohsawa I, Endo M, Ohi H.: Acute alteration in bone mineral density and biochemical markers for bone metabolism in nephritic patients receiving high-dose glucocorticoid and one-cycle etidronate therapy. Calcif Tissue Int. 66 : 195199, 2000.

27) Godschalk MF, Downs RW : Effect of shortterm glucocorticoids on serum osteocalcin in healthy young men. $J$ Bone Miner Res. 3 : 113$115,1988$.

28) Nielsen HK, Charles P, Mosekilde L. : The effect of single oral doses of prednisone on the circadian rhythm of serum osteocalcin in normal subjects. J Clin Endocrinol Metab. 67 : 1025-1030, 1988.

29) Prummel MF, Wiersinga WM, Lips P, Sanders GT, Sauerwein HP. : The course of biochemical parameters of bone turnover during treatment with corticosteroids. J Clin Endocrinol Metab. 72 : 382-386, 1991.

30) Paglia F, Dionisi S, De Geronimo S, Rosso R, Romagnoli E, Raejntroph N, Ragno A, Celi M, Pepe J, D'Erasmo E, Minisola S. : Biomarkers of bone turnover after a short period of steroid therapy in elderly men. Clin Chem. $47: 1314-$ 1316, 2001.

31) Ardissone P, Rota E, Durelli L, Limone P, Isaia GC. : Effects of high doses of corticosteroids on bone metabolism. J Endocrinol Invest. 25 : 129-133, 2002.

32) Sasaki N, Kusano E, Ando $Y$, Nemoto J, Iimura $\mathrm{O}$, Ito $\mathrm{C}$, Takeda $\mathrm{S}$, Yano $\mathrm{K}$, Tsuda $\mathrm{E}$, Asano Y.: Changes in osteoprotegerin and markers of bone metabolism during glucocorti- coid treatment in patients with chronic glomerulonephritis. Bone. 30 : 853-858, 2002.

33) Sasaki N, Kusano E, Ando Y, Yano K, Tsuda E, Asano Y. Glucocorticoid decreases circulating osteoprotegerin (OPG) : possible mechanism for glucocorticoid induced osteoporosis. Nephrol Dial Transplant. 16 : 479-482, 2001.

34) Saarela T, Risteli J, Koivisto M. : Effects of short-term dexamethasone treatment on collagen synthesis and degradation markers in preterm infants with developing lung disease. Acta Paediatr. 92 : 588-594, 2003.

35) Saarela T, Risteli J, Kauppila A, Koivisto M. : Effect of short-term antenatal dexamethasone administration on type I collagen synthesis and degradation in preterm infants at birth. Acta Paediatr. 90 : 921-925, 2001.

36) Meduri GU, Tolley EA, Chinn A, Stentz F, Postlethwaite A. : Procollagen types I and III aminoterminal propeptide levels during acute respiratory distress syndrome and in response to methylprednisolone treatment. Am J Respir Crit Care Med. 158 : 1432-1441, 1998.

37) Webster JC, Cidlowski JA. : Mechanisms of Glucocorticoid-receptor-mediated Repression of Gene Expression. Trends Endocrinol Metab. 10 : 396-402, 1999.

38) Peterkofsky B, Gosiewska A, Singh K, Pearlman S, Mahmoodian F. : Species differences in cis-elements of the proalphal(I) procollagen promoter and their binding proteins. J Cell Biochem. 73 : 408-422, 1999.

39) Ueland T, Bollerslev J, Godang K, Müller F, Frøland SS, Aukrust P. : Increased serum osteoprotegerin in disorders characterized by persistent immune activation or glucocorticoid excess-possible role in bone homeostasis. Eur $J$ Endocrinol. 145 : 685-690, 2001.

40) Fahrleitner A, Prenner G, Leb G, Tscheliessnigg $\mathrm{KH}$, Piswanger-Sölkner $\mathrm{C}$, ObermayerPietsch B, Portugaller HR, Berghold A, Dobnig H. : Serum osteoprotegerin is a major determinant of bone density development and prevalent vertebral fracture status following cardiac transplantation. Bone. 32 : 96-106, 2003.

41) Dovio A, Perazzolo L, Osella G, Ventura M, Termine A, Milano E, Bertolotto A, : Angeli A. Immediate fall of bone formation and transient increase of bone resorption in the course of high-dose, short-term glucocorticoid therapy in young patients with multiple sclerosis. J Clin 
Endocrinol Metab. 89 : 4923-4928, 2004.

42) Kuroki Y, Kaji H, Kawano S, Kanda F, Takai Y, Kajikawa M, Sugimoto T.: Short-term effects of glucocorticoid therapy on biochemical markers of bone metabolism in Japanese patients: a prospective study. J Bone Miner Metab. 26 : 271-278, 2008.

43) Rogers A, Eastell R. : Circulating osteoprotegerin and receptor activator for nuclear factor kappaB ligand: clinical utility in metabolic bone disease assessment. J Clin Endocrinol Metab. 90 : 6323-6331, 2005.

44）折茂 肇, 骨粗鬆症の予防と治療ガイドライ ン作成委員会：骨粗鬆症の予防と治療ガイド ライン 2006 年版, ライフサイエンス出版, 2006.

45) Saag KG, Emkey R, Schnitzer TJ, Brown JP, Hawkins F, Goemaere S, Thamsborg G, Liberman UA, Delmas PD, Malice MP, Czachur M, Daifotis AG. : Alendronate for the prevention and treatment of glucocorticoid-induced osteoporosis. Glucocorticoid-Induced Osteoporosis Intervention Study Group. $N$ Engl J Med. 339 : 292-299, 1998.

46) Adachi JD, Saag KG, Delmas PD, Liberman UA, Emkey RD, Seeman E, Lane NE, Kaufman JM, Poubelle PE, Hawkins F, CorreaRotter R, Menkes CJ, Rodriguez-Portales JA, Schnitzer TJ, Block JA, Wing J, McIlwain HH, Westhovens R, Brown J, Melo-Gomes JA, Gruber BL, Yanover MJ, Leite MO, Siminoski KG, Nevitt MC, Sharp JT, Malice MP, Dumortier T, Czachur M, Carofano W, Daifotis A. : Two-year effects of alendronate on bone mineral density and vertebral fracture in patients receiving glucocorticoids : a randomized, double-blind, placebo-controlled extension trial. Arthritis Rheum. 44 : 202-211, 2001.

47) Wallach S, Cohen S, Reid DM, Hughes RA, Hosking DJ, Laan RF, Doherty SM, Maricic M, Rosen C, Brown J, Barton I, Chines AA. : Effects of risedronate treatment on bone density and vertebral fracture in patients on corticosteroid therapy. Calcif Tissue Int. 67 : 277-
$285,2000$.

48) Adachi JD, Bensen WG, Brown J, Hanley D, Hodsman A, Josse R, Kendler DL, Lentle B, Olszynski W, Ste-Marie LG, Tenenhouse A, Chines AA. : Intermittent etidronate therapy to prevent corticosteroid-induced osteoporosis. $N$ Engl J Med. 337 : 382-387, 1997.

49) de Nijs RN, Jacobs JW, Algra A, Lems WF, Bijlsma JW. : Prevention and treatment of glucocorticoid-induced osteoporosis with active vitamin D3 analogues : a review with metaanalysis of randomized controlled trials including organ transplantation studies. Osteoporos Int. 15 : 589-602, 2004.

50) Saag KG, Shane E, Boonen S, Marín F, Donley DW, Taylor KA, Dalsky GP, Marcus R. : Teriparatide or alendronate in glucocorticoidinduced osteoporosis. N Engl J Med. 357 : 2028-2039, 2007.

51) Nawata H, Soen S, Takayanagi R, Tanaka I, Takaoka K, Fukunaga M, Matsumoto T, Suzuki Y, Tanaka H, Fujiwara S, Miki T, Sagawa A, Nishizawa Y, Seino Y. Subcommittee to Study Diagnostic Criteria for Glucocorticoid-Induced Osteoporosis. Guidelines on the management and treatment of glucocorticoidinduced osteoporosis of the Japanese Society for Bone and Mineral Research (2004). J Bone Miner Metab. 23 : 105-109, 2005.

52) Grossman JM, Gordon R, Ranganath VK, Deal C, Caplan L, Chen W, Curtis JR,Furst DE, McMahon M, Patkar NM, Volkmann E, Saag KG. : American College of Rheumatology 2010 recommendations for the prevention and treatment of glucocorticoid-induced osteoporosis. Arthritis Care Res (Hoboken). 62 : 1515-1526, 2010.

53) http://www.sheffield.ac.uk/FRAX/

54) Kanis JA, Johansson H, Oden A, Johnell O, de Laet C, Melton III LJ, Tenenhouse A, Reeve J, Silman AJ, Pols HA, Eisman JA, McCloskey EV, Mellstrom D. : A meta-analysis of prior corticosteroid use and fracture risk. J Bone Miner Res. 19 : 893-899, 2004. 